\title{
Gambaran Perilaku Masyarakat dan Keputusan Tidak Menggunakan Gigi Tiruan Lepasan
}

\author{
Dita C. Kaida, Christy N. Mintjelungan, Dinar A. Wicaksono
}

\author{
Program Studi Pendidikan Dokter Gigi Fakultas Kedokteran Universitas Sam Ratulangi, \\ Manado, Sulawesi Utara, Indonesia \\ Email: ditakaida@gmail.com
}

\begin{abstract}
Teeth play an important role in chewing process, speech function, and as an aesthetics for the formation of facial profiles. Problems that often occur in dental and oral health, such as caries which causes tooth decay, therefore, extraction is needed. The solution to tooth loss is to use dentures, however, not everyone wants to do that. There are factors that influence a person's condition in taking action, namely behavior. Health behavior is everything related to one's actions in maintaining and improving one's health. A person's decision to use or not use dentures is influenced by economic factors, knowledge, time, and experience.Thi study was aimed to obtain the community behavior related to the decision not to use removable dentures. This was a literature study using two databases, namely Google Scholar and Digital Reference Garba. Data were analyzed by using a cross sectional study design. The results showed that the community behavior was categorized as good. The community's decision not to use removable dentures was influenced by several factors, namely economy status, knowledge, time, and experience. In conclusion, although the community behavior was categorized as good, there were still many of them who lost their teeth but did not replace their missing teeth with artificial teeth due to a variety of factors.

Keywords: behaviour, removable denture
\end{abstract}

\begin{abstract}
Abstrak: Gigi berperan penting dalam membantu proses pengunyahan, fungsi bicara, dan sebagai estetika pembentukan profil wajah. Masalah kesehatan gigi dan mulut seperti karies menyebabkan rusaknya gigi sehingga perlu pencabutan. Prevalensi penggunaan gigi tiruan tidak sebanding dengan prevalensi kehilangan gigi di masyarakat. Terdapat faktor yang memengaruhi keadaan seseorang dalam melakukan tindakan yaitu perilaku. Pengambilan keputusan seseorang untuk menggunakan atau tidak menggunakan gigi tiruan juga dipengaruhi oleh beberapa faktor yaitu faktor ekonomi, pengetahuan, waktu, dan pengalaman. Penelitian ini bertujuan untuk mengetahui gambaran perilaku masyarakat dan keputusan tidak menggunakan gigi tiruan lepasan. Jenis penelitian ialah literatur reviewe, dengan sumber data diperoleh dari dua database yaitu Google Scholar dan Garba Rujukan Digital kemudian dianalisis dengan desain potong lintang. Hasil penelitian mendapatkan bahwa masih banyak masyarakat yang kehilangan gigi tetapi tidak menggantikan gigi yang hilang dengan gigi tiruan. Gambaran perilaku masayarakat dikategorikan baik dan untuk keputusan masyarakat tidak menggunakan gigi tiruan lepasan dipengaruhi oleh beberapa faktor yaitu faktor ekonomi, pengetahuan, waktu dan pengalaman. Simpulan penelitian ini ialah walaupun gambaran perilaku masayarakat dikategorikan baik namun masih banyak masyarakat kehilangan gigi tetapi tidak menggantikan gigi yang hilang dengan gigi tiruan, yang dipengaruhi oleh berbagai faktor.
\end{abstract}

Kata kunci: perilaku, gigi tiruan lepasan

\section{PENDAHULUAN}

Gigi merupakan salah satu komponen dalam rongga mulut yang turut berperan penting dalam membantu proses pengu- nyahan dan pencernaan. Selain itu, struktur gigi yang baik juga berperan dalam estetika pembentukan profil wajah. ${ }^{1}$ Kerusakan gigi dapat memengaruhi kesehatan anggota 
tubuh lainnya. Masalah yang sering terjadi pada kesehatan gigi dan mulut seperti karies yang menyebabkan rusaknya gigi sehingga perlu pencabutan serta penyakit periodontal yang terus meningkat dan men-jadi salah satu faktor penyebab kehilangan gigi. ${ }^{2,3}$ Kehilangan gigi meningkat seiring dengan dengan bertambhanya usia akibat efek kumulatif dari karies dan penyakit periodontal. ${ }^{4}$ Dampak kehilangan gigi dapat menyebabkan berkurangnya kemampuan dalam proses pengunyahan makanan, berkurangnya kemampuan untuk berbicara dengan baik, serta memengaruhi keadaan fisik seperti penampilan estetik dan psikologis seperti kurangnya percaya diri. ${ }^{5,6}$

Data Riset Kesehatan Dasar (RISKESDAS) tahun 2018 mencatat proporsi sebesar $57,6 \%$ dari masalah gigi dan mulut ialah masalah kehilangan gigi, yang meningkat dari data RISKESDAS pada tahun 2013 sebesar $25,9 \%{ }^{7}$ Untuk persentase kehilangan gigi di Indonesia yaitu sebesar 19,0\%. Untuk karakteristik kelompok usia untuk masalah kehilangan gigi terdapat pada usia 45-54 tahun yaitu 23,6\%. Semakin bertambahnya usia semakin meningkat persentase kehilangan gigi. Walaupun persentase kehilangan gigi meningkat namun tidak semua individu yang kehilangan gigi menggantikan gigi yang hilang dengan menggunakan gigi tiruan. Persentase masyarakat yang menggunakan gigi tiruan ialah sebesar $1,4 \%{ }^{8}$

Prevalensi penggunaan gigi tiruan ternyata sangat kecil dan tidak sebanding dengan persentase kehilangan gigi di masyarakat. Banyak kejadian kehilangan gigi di masyarakat namun kesadaran masyarakat masih kurang untuk menggantikan gigi yang hilang. Solusi untuk masalah kehilangan gigi ialah menggunakan gigi tiruan, tetapi terdapat beberapa faktor yang memengaruhi seseorang dalam melakukan suatu tindakan seperti perilaku.

Perilaku merupakan reaksi atau respon seseorang terhadap stimulus dan mempunyai tujuan baik yang disadari maupun tidak disadari. Interaksi tersebut amat kompleks sehingga kadang tidak sempat dipikirkan penyebab seseorang menerapkan perilaku tertentu. ${ }^{9}$
Kehilangan gigi merupakan hal umum yang sering terjadi pada masyarakat saat ini. Pengambilan keputusan sesorang untuk tidak menggunakan gigi tiruan dipengaruhi juga oleh beberapa faktor, seperti lamanya waktu pembuatan gigi tiruan, faktor ekonomi yakni mahalnya biaya pembuatan gigi tiruan, dan tingkat pendidikan seseorang yang mencakup pengetahuan, antara lain kurangnya pengetahuan masyarakat tentang manfaat dan fungsi penggunaan gigi tiruan. ${ }^{10,11}$

Berdasarkan latar belakang yang telah diuraikan maka penulis tertarik untuk mengetahui gambaran perilaku masyarakat dan keputusan tidak menggunakan gigi tiruan lepasan.

\section{METODE PENELITIAN}

Penelitian ini merupakan suatu literatur review yang dilakukan pada bulan JuniDesember 2020. Data penelitian diperoleh melalui pencarian data menggunakan dua database yaitu Google Scholar dan Garba Rujukan Digital. Kata kunci dalam pencarian jurnal yaitu perilaku dan gigi tiruan lepasan. Kriteria inklusi penelitian ini yakni: jurnal terbitan tahun 2010-2020, berbahasa Indonesia dan Inggris, dan sampel penelitian yang tidak menggunakan gigi tiruan lepasan.

Berdasarkan hasil pencarian literatur, didapatkan sebanyak 320 artikel menggunakan Google Scholar dan Garba Rujukan Digital $(n=320)$ yang sesuai dengan kata kunci tersebut. Hasil pencarian yang diperoleh kemudian disaring berdasarkan judul dan abstrak yang sesuai topik bahasan. Literatur yang sama tetapi terdapat di database yang berbeda hanya dihitung sebagai satu literatur, sehingga didapatkan 17 literatur $(n=17)$. Setelah disaring kembali berdasarkan kriteria inklusi dan eksklusi, maka didapatkan lima literatur $(n=5)$ dalam penelitian ini.

\section{HASIL PENELITIAN}

Setelah melalui tahap seleksi, didapatkan lima literatur yang memenuhi kriteria inklusi dan eksklusi. Tabel 1 memperlihatkan hasil kajian lima literatur yang dipakai dalam penelitian ini. 
Tabel 1. Hasil kajian literatur yang dipakai dalam penelitian

\begin{tabular}{|c|c|c|c|}
\hline $\begin{array}{l}\text { Peneliti dan } \\
\text { Tahun }\end{array}$ & Judul & Metode dan Sampel & Hasil \\
\hline $\begin{array}{l}\text { Raviola, } \\
2020^{12}\end{array}$ & $\begin{array}{l}\text { Perilaku masyarakat ten- } \\
\text { tang pemakaian gigi tiruan } \\
\text { di Dusun } 1 \text { Desa Taliku- } \\
\text { main Kabupaten Rokan } \\
\text { Hulu }\end{array}$ & $\begin{array}{l}\text { Cross sectinal } \\
\text { study. Sampel } 85 \\
\text { responden. }\end{array}$ & $\begin{array}{l}\text { Responden yang menggunakan gigi } \\
\text { tiruan }(8,2 \%) \text { dan yang tidak menggu- } \\
\text { nakan gigi tiruan }(91,8 \%) \text {. Dipenga-ruhi } \\
\text { oleh beberapa faktor, umur, jenis } \\
\text { kelamin, pendidikan, pekerjaan, pe- } \\
\text { ngetahuan, sikap dan tindakan. }\end{array}$ \\
\hline $\begin{array}{l}\text { Gumayesty, } \\
2017^{13}\end{array}$ & $\begin{array}{l}\text { Gambaran pengetahuan } \\
\text { dan sikap masyarakat ten- } \\
\text { tang pemakaian gigi tiruan } \\
\text { di Desa Mayang Pongkai } \\
\text { Kecamatan Kamapar Kiri } \\
\text { Tengah Kabupaten Kam- } \\
\text { par }\end{array}$ & $\begin{array}{l}\text { Cross sectional } \\
\text { study. Sampel } 96 \\
\text { responden. }\end{array}$ & $\begin{array}{l}\text { Responden yang tidak memakai gigi } \\
\text { tiruan }(72,9 \%) \text { dan responden yang } \\
\text { memakai gigi tiruan }(27,1 \%) \text {. } \\
\text { Pengetahuan responden baik }(90 \%) \text { dan } \\
\text { kurang baik }(10.4 \%) \text {. Sikap responden } \\
\text { kurang baik }(80,2 \%) \text { dan baik }(19.8 \%) \text {. }\end{array}$ \\
\hline Werluka, $2016^{14}$ & $\begin{array}{l}\text { Faktor-faktor yang mela- } \\
\text { tarbelakangi masyarakat } \\
\text { Desa Beringin Kecamatan } \\
\text { Belang tidak menggunakan } \\
\text { gigi tiruan }\end{array}$ & $\begin{array}{l}\text { Cross sectional } \\
\text { study. Sampel } 72 \\
\text { responden }\end{array}$ & $\begin{array}{l}\text { Ada } 3 \text { faktor terbesar yang } \\
\text { melatarbelakangi yaitu : Faktor } \\
\text { ekonomi }(86,11 \%) \text {, faktor pengetahuan } \\
(56,94 \%) \text { dan faktor pengalaman } \\
(47,22 \%)\end{array}$ \\
\hline $\begin{array}{l}\text { Pongisibidang, } \\
2013^{15}\end{array}$ & $\begin{array}{l}\text { Alasan masyarakat Kelu- } \\
\text { rahan Sario Tumpaan tidak } \\
\text { menggunakan gigi tiruan }\end{array}$ & $\begin{array}{l}\text { Cross sectional } \\
\text { study. Sampel } 100 \\
\text { responden }\end{array}$ & $\begin{array}{l}\text { Alasan masyarakat yaitu: Alasan } \\
\text { pengetahuan }(61 \%) \text {, alasan biaya } \\
(59 \%) \text {, alasan waktu( } 67 \%) \text {, alasan } \\
\text { pelayanan kesehatan }(29 \%) \text { dan alasan } \\
\text { lain }(20 \%) \text {. }\end{array}$ \\
\hline Situni, $2013^{16}$ & $\begin{array}{l}\text { Identifikasi faktor peng- } \\
\text { hambat seseorang menggu- } \\
\text { nakan gigi tiruan }\end{array}$ & $\begin{array}{l}\text { Cross sectional } \\
\text { study. Sampel } 108 \\
\text { responden }\end{array}$ & $\begin{array}{l}\text { Faktor penghambat: Faktor ekonomi } \\
(70,37 \%) \text {, faktor pengetahuan }(44,44 \%) \\
\text { dan faktor waktu }(30,56 \%) \text {. }\end{array}$ \\
\hline
\end{tabular}

\section{BAHASAN}

Hasil penelitian ini memperlihatkan bahwa masih banyak ditemukan masyarakat yang kehilangan gigi tetapi tidak menggantikan gigi yang hilang dengan menggunakan gigi tiruan. Banyak hal yang dapat memengaruhi perilaku seseorang untuk menggunakan atau tidak menggunakan gigi tiruan lepasan, salah satunya ialah faktor predisposisi. Pengambilan keputusan seseorang untuk tidak menggunakan gigi tiruan juga dipengaruhi oleh beberapa faktor seperti mahalnya pembuatan gigi tiruan, lamanya waktu pembuatan gigi tiruan, dan kurangnya pengetahuan masyarakat tentang manfaat dan fungsi gigi tiruan, faktor waktu, dan pengalaman. ${ }^{17,18}$

Penelitian yang dilakukan Raviola ${ }^{12} \mathrm{di}$ Kabupaten Rokan Hulu menunjukkan bahwa dalam hal perilaku masyarakat tentang pemakaian gigi tiruan, diperoleh yang menggunakan gigi tiruan sebesar 8,2\% dan yang tidak menggunakan gigi tiruan sebesar
91,8\%. Karakteristik usia responden dari sebagian besar yang tidak menggunakan gigi tiruan masuk kedalam kategori lansia awal (46-55 tahun) berjumlah 31,8\%. Untuk jenis kelamin dalam penelitian ini sebagian besar ialah perempuan $(68,2 \%)$. Untuk pendidikan responden sebagian besar responden berpendidikan SD (41,2\%). Untuk pekerjaan responden sebagian besar ialah petani $(48,2 \%)$. Untuk perilaku dalam penelitian ini, yang diteliti yaitu pengetahuan dikategorikan baik $70,1 \%$, sikap dikategorikan baik $65,4 \%$, dan tindakan dikategorikan baik $52.9 \%$. Dalam hal kategori usia yaitu lansia awal (46-55 tahun) diperoleh sebesar $31,8 \%$. Raviola ${ }^{12}$ berasumsi bahwa pengetahuan kurang tentang pentingnya pemakaian gigi tiruan sebagai pengganti gigi yang hilang dan juga faktor ekonomi sehingga responden tidak menggunakan gigi tiruan.

Penelitian kedua yang dilakukan oleh Gumayesty $^{13}$ di desa Mayang Pongkai Kecamatan Kampar Kiri Tengah Kabupaten 
Kampar melaporkan bahwa responden yang tidak menggunakan gigi tiruan sebesar $72,9 \%$ dan yang menggunakan gigi tiruan sebesar $27,1 \%$. Hasil penelitian tersebut menunjukkan bahwa sebesar $58,3 \%$ responden yang tidak menggunakan gigi tiruan terdapat pada usia 35-40 tahun. Untuk jenis kelamin didapatkan bahwa responden perempuan lebih banyak daripada laki-laki yaitu sebanyak $59.4 \%$. Untuk pendidikan responden, dilaporkan bahwa sebagian besar responden tidak tamat sekolah yaitu sebesar $30,2 \%$. Untuk pekerjaan responden sebagian besar ialah petani sebesar $37.5 \%$. Untuk perilaku dalam penelitian tersebut didapatkan bahwa pengetahuan responden dikategorikan baik sebesar $90 \%$ dan sikap responden dikategorikan sikap negatif/ kurang baik sebesar $80,2 \%$. Gumayesty ${ }^{13}$ berasumsi bahwa sikap negatif responden disebabkan karena masyarakat kurang memperdulikan perawatan gigi tiruan atau kurang memperhatikan gigi mereka sehingga banyak masyarakat lebih memilih kehilangan gigi dari pada memakai gigi tiruan.

Penelitian yang dilakukan Werluka et $\mathrm{al}^{14}$ di Kecamatan Beringin mendapatan bahwa pada 72 responden yang tidak menggunakan gigi tiruan, jenis kelamin terbanyak ialah laki-laki (51,39\%). Untuk karakteristik usia, yang paling banyak didapatkan pada responden kehilangan gigi ialah usia 40-49 tahun $(31,94 \%)$. Untuk tingkat pendidikan sebagian besar responden yang kehilangan gigi memiliki tingkat pendidikan SD $(54,17 \%)$. Faktor yang melatarbelakangi masyarakat untuk memutuskan tidak menggunakan gigi tiruan antara lain yaitu faktor ekonomi. Terdapat $86,11 \%$ responden menunda atau tidak mau menggunakan gigi tiruan dengan alasan mahal; faktor pengetahuan, 56,94\% responden mengaku kurang memahami dampak kehilangan gigi; dan faktor pengalaman, $47,2 \%$ pengalaman yang dialami dapat menimbulkan kesan positif dan negatif dalam memutuskan untuk menggunakan gigi tiruan.

Penelitian yang dilakukan oleh Pongsibidang et al ${ }^{15}$ menyatakan bahwa keputusan seseorang tidak menggunakan gigi tiruan dipengaruhi oleh beberapa alasan, yaitu: 1) pengetahuan, $61 \%$ responden tidak mengetahui tentang fungsi dan manfaat gigi tiruan yang menyebabkan masyarakat tidak menggunakan gigi tiruan; 2) alasan biaya, 59\% responden menyatakan bahwa pembuatan gigi tiruan mahal; 3) alasan waktu, 67\% responden menyatakan sibuk atau tidak ada waktu dalam perawatan gigi tiruan; 4) alasan pelayanan kesehatan, 29\% responden menyatakan bahwa pelayanan di rumah sakit rumit, sehingga masyarakat malas untuk perawatan gigi tiruan di rumah sakit ; 5) alasan lainnya, 20\% respoden merasa tidak perlu menggunakan gigi tiruan karena kehilangan gigi hanya terjadi pada gigi belakang saja.

Penelitian yang dilakukan oleh Situni et al $^{16}$ di Kelurahan Maasing Kota Manado menyatakan bahwa masih banyak orang yang tidak menggunakan gigi tiruan disebabkan oleh beberapa faktor penghambat, yaitu: 1) faktor ekonomi, 70,37\% responden menyatakan bahwa pembuatan gigi tiruan membutuhkan biaya yang tidak sedikit; 2) faktor pengetahuan, sebesar $44,44 \%$ masyarakat menyatakan masih kurang memahami dampak kehilangan gigi. Faktor pengetahuan seseorang juga dilihat dari tingkat pendidikannya. Masyarakat Kelurahaan Maasing memiliki tingkat pendidikan rata-rata SD; 3) faktor waktu, $30.56 \%$ responden menyatakan tidak memiliki waktu dalam pembuatan gigi tiruan.

\section{SIMPULAN}

Gambaran perilaku masayarakat dikategorikan baik namun masih banyak masyarakat yang kehilangan gigi tidak menggantikan gigi yang hilang dengan gigi tiruan. Hal ini dipengaruhi oleh berbagai faktor, yaitu: faktor ekonomi, pengetahuan, waktu, dan pengalaman.

\section{Konflik Kepentingan}

Penulis menyatakan tidak terdapat konflik kepentingan dalam studi ini.

\section{DAFTAR PUSTAKA}

1. Erwana AF. Seputaran Kesehatan Gigi dan Mulut. Yogyakarta: Rapha Publishing, 2013; p.1-6. 
2. Budiharto. Pengantar Ilmu Perilaku Kesehatan dan Pendidikan Kesehatan Gigi. Jakarta: EGC, 2013; p. 17.

3. Kidd EAM, Bechal SJ. Dasar-dasar Karies Penyakit dan Penanggulangannya. Jakarta: EGC, 2013; p. 3.

4. Peranci A. Behaviour and hyiene habits of complete denture wearers. Braz Dent J. 2010;21(3):52.

5. Adhiatmitha KE, Pertiwi NKFR, Susanti DNA. Faktor-faktor yang berkaitan dengan tingkat perilaku pemeliharaan kebersihan gigi tiruan lepasan aklirik pada lansia di Desa Penatahan Kabupaten Tabanan Bali. BDJ. 2018;2(1):18

6. Emini. Gigi tiruan dan perilaku ibadah. Jurnal Health Quality. 2013;4(1).

7. Departemen Kesehatan Republik Indonesia. Laporan Riset Kesehatan dasar Nasional 2007 dan 2013. Jakarta: Badan Penelitian dan Pengembangan Kesehatan, 2008; p. 146-76.

8. Departemen Kesehatan Republik Indonesia. Laporan Riset Kesehatan Dasar Nasional 2018. Jakarta: Badan Penelitian dan Pengembangan Kesehatan, 2019; p. 182-7.

9. Notomodjo S. Ilmu dan Seni Kesehatan Masyarakat. Jakarta: Rineka Cipta, 2014.

10. Chairunnisa, Sofya PA, Novita CF. Gambaran tingkat pengetahuan masyarakat tentang kehilangan gigi dan pemakaian gigi tiruan di Kecamatan Jaya Baru
Banda Aceh. J Caninus Denstistry, 2017;2(4):143.

11. Siagian KV. Kehilangan sebagian gigi pada rongga mulut. e-CliniC. 2016;4(1):1-6.

12. Raviola. Perilaku masyarakat tentang pemakaian gigi tiruan di Dusun I Desa Talikumain Kabupaten Rokan Hulu. Jurnal Kesehatan Masyarakat. 2020; 4(1):52-3.

13. Gumayesty Y. Gambaran pengetahuan dan sikap masyarakat tentang pemakaian gigi tiruan di Desa Mayang Pongkai Kecamatan Kampar Kiri Tengah Kabupaten Kampar. Jurnal Photon. 2017;8(1):8-11.

14. Werluka ND, Leman MA, Parengkuan WG. Faktor-faktor yang melatarbelakangi masyarakarat desa Beringin Kecamatan Belang tidak menggunakan gigi tiruan. e-GiGi. 2016;5(1):186-8.

15. Pongsibidang H, Wowor VNS, Supit A. Alasan masyarakat kelurahan Sario Tumpaan tidak menggunakan gigi tiruan. e-GiGi. 2013;1(2):1-7.

16. Situni Jl, Wowor VNS, Juliatri. Identifikasi faktor peghambat seseorang menggunakan gigi tiruan. e-GiGi. 2013:1(2):2-5.

17. Titjo OC, Lampus BS, Juliatri. Perilaku masyarakat penggunaan gigi tiruan lepasan. e-GiGi. 2013;2(2):2-5.

18. Budiman J, Yuwono L, ediotor. Praktik Kesehatan Gigi Masyarakat Jakarta: EGC, 2013; p. 42-60. 